\title{
Gambaran kadar gula darah tikus wistar diabetes hasil induksi streptozotocin dosis tunggal
}

\author{
Imron Rosyadi, Ella Romadhona, Ajeng Tyas Utami, Yayik Nur Hijrati, \\ Christin Marganingsih Santosa \\ Departemen Patologi Klinik, Fakultas Kedokteran Hewan, Universitas Gadjah Mada, Yogyakarta
}

\begin{abstract}
ABSTRAK: Penyakit diabetes mellitus adalah penyakit metabolik yang ditandai dengan adanya kenaikan kadar gula dalam darah. Penelitian ini bertujuan untuk melihat gambaran kadar gula darah tikus wistar yang diinduksi diabetes dengan streptozotocin. Tikus yang digunakan adalah tikus Wistar jantan sebanyak 20 ekor, umur sekitar 2 bulan dengan berat badan 180-250 gram. Tikus dibagi menjadi dua kelompok, masing-masing kelompok 10 ekor tikus sebagai kelompok perlakuan (I) dan kelompok kontrol (II). Kelompok I dipuasakan selama 24 jam kemudian diinjeksi streptozotocin 1 kali dengan dosis 40 $\mathrm{mg} / \mathrm{kg}$ bb yang dilarutkan dalam bufer sodium sitrat $0,1 \mathrm{M} \mathrm{pH} \mathrm{4,0.} \mathrm{Tikus} \mathrm{diambil} \mathrm{darah} \mathrm{pada} \mathrm{jam} \mathrm{ke-0,} \mathrm{6,} \mathrm{12,} \mathrm{24,} \mathrm{48,} \mathrm{60,} \mathrm{72,}$ 84 dan 96 post induksi diabetes untuk diperiksa kadar gula darah. Hasil penelitian menunjukkan rata-rata kadar gula darah tikus masih dalam keadaan normal pada jam ke-0 sebesar 90,6 $\pm 15,88 \mathrm{gr} / \mathrm{dL}$ dan jam ke-6 126 $\pm 11,73$ gr/dl lalu menurun pada

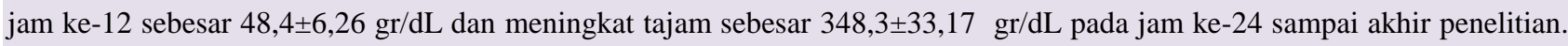
Hasil dari penelitian ini menunjukkan streptozotocin dapat menginduksi tikus menjadi diabetes mellitus.

Kata kunci:

tikus wistar, diabetes, kadar gula darah, streptozotocin
\end{abstract}

\section{- PENDAHULUAN}

Data dari International Diabetes Federation, di tahun 2014 ada 382 juta penderita diabetes di seluruh dunia dengan angka kematian mencapai 5,1 juta orang artinya setiap 6 detik, ada 1 penderita diabetes yang meninggal. Angka tersebut diperkirakan pada tahun 2035 akan mencapai 2 kali lipat hingga 592 juta jiwa. Indonesia berada di nomor 7 dengan jumlah penderita sebanyak 8,5 juta orang dan di posisi teratas, ada Cina (98,4 juta jiwa), India (65,1 juta jiwa), dan Amerika (24,4 juta jiwa) (Mutiana, 2011) (Lamondo, 2014).

\section{- MATERI DAN METODE}

Materi: Tikus yang digunakan adalah tikus Wistar sebanyak 20 ekor jantan, umur sekitar 2 bulan, dengan berat badan 180-250 gram. Tikus diperoleh dari Laboratorium Farmakologi dan Toksikologi, Fakultas Farmasi, Universitas Gadjah Mada, Yogyakarta. Streptozotocin yang diperoleh dibeli dari perusahaan Nakalai, Japan dan sodium sitrat bufer sebagai pelarut diperoleh dari Laboratorium Patologi Klinik, Fakultas Kedokteran Hewan, Universitas Gadjah Mada, Yogyakarta. Tikus diberikan minum dan pakan secara ad libitum, dan bedding tikus berupa serutan kayu yang telah dioven. Metode: Tikus dibagi menjadi dua kelompok, kelompok I sebanyak 10 ekor tikus sebagai kelompok perlakuan dan kelompok II sebanyak 10 ekor tikus sebagai kelompok kontrol. Kelompok I dipuasakan selama 24 jam kemudian diinjeksi streptozotocin 1 kali dengan dosis $40 \mathrm{mg} / \mathrm{kg}$ bb yang dilarutkan dalam bufer sodium sitrat $0,1 \mathrm{M} \mathrm{pH} 4,0$. Tikus akan mengalami kenaikan kadar gula darah dalam waktu 48-72 jam postinduksi. Pada penelitian ini, tikus diabetes adalah tikus yang diinduksi streptozotocin yang dalam 48 jam akan menyebabkan peningkatan kadar glukosa darah > 230 $\mathrm{mg} / \mathrm{dL}$. Jam ke-0 adalah jam post induksi streptozotocin sampai tikus menjadi diabetes. Tikus akan diambil darahnya pada jam ke-0, 6, 12, 24, 48, 60, 72, 84 dan 96 post induksi diabetes untuk diperiksa gula darah. Analisa data: Analisis kadar glukosa darah digunakan analisis untuk. Data yang diproleh dianalisa multivariate secara statistik dengan ANOVA dan deskriptif untuk mengetahui pengaruh streptozotocin terhadap kadar glukosa darah diantara kelompok perlakuan dan kelompok normal.

\section{- HASIL DAN PEMBAHASAN}

Kelompok I (diabetes) terjadi peningkatan kadar glukosa darah yang signifikan $(\mathrm{p}<0,05)$ yaitu pada jam ke-0 dan jam ke-6 setelah perlakuan, rata-rata glukosa darahnya berkisar normal yaitu 90,6 $\pm 15,88 \mathrm{mg} / \mathrm{dL}$ dan $126 \pm 11,73 \mathrm{mg} / \mathrm{dL}$ (Gambar 1). Kadar gula darah tikus kemudian mengalami penurunan yang signifikan dibawah normal pada jam ke-12 perlakuan menjadi 48,4 $\pm 6,26 \mathrm{mg} / \mathrm{dL}$. Jam ke-24 glukosa darah mengalami kenaikan yang signifikan menjadi

Diterima: 03-04-2018 | Direvisi: 17-05-2018 | Disetujui: 30-05-2018 (C) 2018 CC-BY-SA. Ini adalah artikel Open Access yang didistribusikan berdasarkan ketentuan dari Creative Commons Attribution ShareAlike 4.0 International License (https://creativecommons.org/licenses/by-sa/4.0/). 
$348,3 \pm 33,17 \mathrm{mg} / \mathrm{dL}$. Kenaikan ini berlangsung stabil berturut-turut setelahnya mulai dari jam ke 36 sebesar $477,5 \pm 75,02 \mathrm{mg} / \mathrm{dL}$, jam ke 48 sebesar 396,6 $\pm 29,66 \mathrm{mg} / \mathrm{dL}$, jam ke 60 sebesar 407,4 $\pm 38,68$ mg.dL, jam ke 72 sebesar $464,1 \pm 86,18 \mathrm{mg} / \mathrm{dL}$, dan jam ke 84 serta jam ke 96 yaitu $525 \pm 77,93 \mathrm{mg} / \mathrm{dL}$ dan $503,1 \pm 90,78 \mathrm{mg} / \mathrm{dL}$. Hal ini memperlihatkan bahwa terjadi kenaikan kadar glukosa darah akibat pemberian streptozotocin.

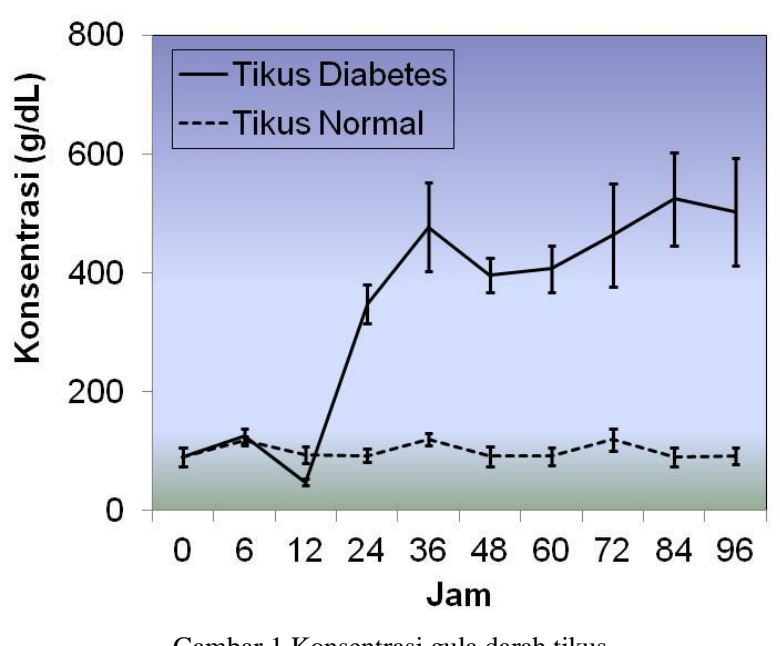

Hasil analisis multivariate diperoleh hasil bahwa ada pengaruh pada kelompok tikus perlakuan terhadap kadar glukosa darah $(\mathrm{p}<0,05)$ dibanding kelompok tikus normal akibat pemberian streptozotocin. Hal ini menunjukkan bahwa streptozotocin berpengaruh signifikan $(\mathrm{p}<0,05)$ dalam meningkatkan kadar glukosa darah tikus Wistar diabetik (Gambar 1).

Perkembangan kadar glukosa darah dilakukan melalui uji lanjutan LSD (Least Significantly Difference) dimana pada kelompok I rata-rata glukosa darah jam ke-0 dan jam ke-6 adalah normal, kemudian jam ke-12 terjadi penurunan yang signifikan dan jam ke-24, 36, 48, 60, 72, 84, 96 terjadi peningkatan kadar glukosa darah yang signifikan $(\mathrm{p}<0,05)$ bila dibandingkan dengan kelompok kontrol. Hasil uji statistik menunjukkan bahwa kelompok I terjadi peningkatan kadar gula darah yang signifikan $(\mathrm{p}<0,05)$ dibandingkan kelompok II. Pemberian streptozotocin memiliki pengaruh yang nyata dalam meningkatkan kadar glukosa darah pada tikus diabetik (Taebe, 2012).

Penelitian menunjukkan bahwa induksi streptozotocin mengakibatkan peningkatan kadar glukosa darah dan tandatanda klinis ke arah diabetes melitus. Hal ini sesuai dengan sifat streptozotocin bahwa dalam menimbulkan gejala, setelah pemberian streptozotocin biasanya terdapat tiga fase yaitu peningkatan kadar glukosa darah (hiperglikemia) dan diikuti penurunan glukosa darah (hipoglikemia), lalu diikuti hiperglikemia permanen (Imron, 2016).

Tikus kelompok II (kontrol) yang tidak diinduksi streptozotocin tidak terjadi penurunan atau pun kenaikan kadar glukosa darah yang signifikan $(\mathrm{p}<0,05)$. Kadar gula darah tikus masih dalam kisaran normal yaitu 70-140 $\mathrm{mg} / \mathrm{dL}$ (Akbarzadeh, 2007). Penelitian ini berhasil menggunakan dosis tunggal streptozotocin sebanyak $40 \mathrm{mg} / \mathrm{kg}$ BB secara intraperitoneal mampu meningkatkan kadar gula tikus dalam waktu 24 jam.

\section{SIMPULAN}

Kadar gula dalam darah tikus akan meningkat dalam waktu 24 jam setelah pemberian dosis tunggal streptozotocin sebanyak 40mg/kg BB tikus secara intraperitoneal.

\section{- INFORMASI PENULIS}

Penulis untuk korespondesi

*IR: imronrosyadi.dvm@gmail.com

Departemen Patologi Klinik, Fakultas Kedokteran Hewan, Universitas Gadjah Mada, Yogyakarta

\section{n TERIMA KASIH}

Terimakasih kami kepada Fakultas Kedokteran Hewan UGM yang telah mendanai penelitian ini melalui skema pendanaan Hibah Penelitian Departemen.

\section{- PUSTAKA ACUAN}

Akbarzadeh A. 2007. Induction of diabetes by streptozotocin in rats. Indian Journal of Clinical Biochemistry 22 (2):60 - 64.

Dorland. 2007. Dorland Illustrated Medical Dictionary. Elsevier Health Science. Philadelphia. pp.412-415.

Imron R. 2016. Potensi anti diabetes melitus serbuk umbi tanaman sarang semut (Myrmecodia tuberose) melalui kajian hematologik, imunologik dan histopatologik organ tikus wistar yang diinduksi streptozotocin. Thesis Magister Sain Veteriner, Fakultas Kedokteran Hewan UGM

Mutiana JP. 2011. Pengaruh pemberian infusa tumbuhan sarang semut (Hydnophytum formicarum) terhadap gambaran histologi pankreas pada tikus (Rattus norvegicus) diabetes terinduksi aloksan. Majalah Kesehatan Pharma Medika 3(1):35-40.

Taebe B. 2012. Uji efek hipoglikemik kombinasi ekstrak etanol propolis dan ekstrak etanol sarang semut (Myrmecodia pendans Merr \& Perry) pada mencit (Mus musculus). Majalah Farmasi dan Farmakologi. 16(3):151-158. 